Lilia Blima Schraiber ${ }^{1}$ André Mota ${ }^{1}$

\section{The social in health: trajectory and contributions of Maria Cecilia Ferro Donnangelo}

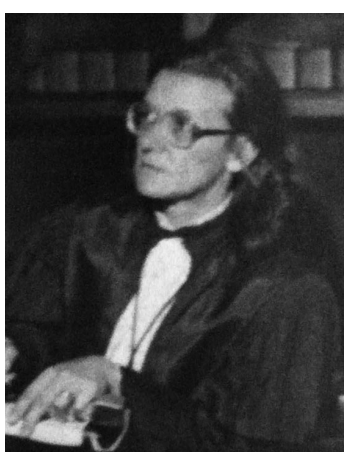

${ }^{1}$ Departamento de Medicina Preventiva, Faculdade de Medicina, Universidade de São Paulo. Av. Dr. Arnaldo 455/2170, Cerqueira César. 01246903 São Paulo SP Brasil. liliabli@usp.br
Abstract This text covers the professional and scientific career of Maria Cecilia Ferro Donnangelo, professor, researcher and influential intellectual in the area of Collective Health. Born in 1940, and killed in a car accident in 1983, she actively participated in the emergence of Collective Health in Brazil and greatly influenced the creation of the sub-areas of Social Science and the Humanities in the health field. Her brief biography, contextualized professional choices and scientific production is hereby presented. Graduated in pedagogy at the time of national developmentalism with a post graduation in Sociology, Donnangelo fell into the triangulated area of Education, Sociology and Health, focusing medicine as a social practice and as a profession in society. Always with an eye to human rights and an ongoing dialogue with the modern Brazilian state and public policy, she examined questions of the social aspects in health and education, as well as questions of health education as a social tool. An educator of great prestige, her published work was limited. However, due to her foundational presence, her writings are classic references with assured presence and contributions for today and also vital to the future development of the Brazilian Collective Health.

Key words Collective health, Health \& history, Social sciences \& health, Cecilia Donnangelo, Health and society 


\section{Introduction}

Maria Cecilia Ferro Donnangelo was a memorable person and a figure of major importance as a politician and a scientist in the area of Collective Health. For those who knew her, she was Cecilia, with a strong personality, style and Italian roots. She spoke quickly, with gestures, as though she were from the interior of São Paulo - drawing out the " $r$ " of the Portuguese words "guaRda-roupa" or "supeR-mercado" (Closet and supermarket, respectively), and when she spoke, she spoke... and spoke a lot.

For many, however, she was Donnangelo, as she was known by those who had access to her only through her publications.

Here we deal with these facets, intending to present their individual trajectory, capturing in her biography traces of specific historical moments and from her production, coming to understand her as a researcher and a great intellectual who built Collective Health. She lived too little and died at age 43 , in a tragic car accident. However, she had a great influence in the field: as an original reference to schools of thought, contributing to reflection in all three sub-areas of Collective Health (Epidemiology, Social Sciences and the Humanities in Health, and the policy/ planning/management/health evaluation); and she was part of those whose production led to the Social Sciences in the field.

\section{Who was Cecilia Donnangelo: the character and the story}

The path which brought her to Collective Health began in a very unusual way ${ }^{1}$. She was born in Araraquara, in the state of São Paulo, on August 19, 1940. She graduated in 1962 in Pedagogy, from the Faculty of Philosophy, Science and Letters of Araraquara (FFCLA), which today belongs to the São Paulo State University, UNESP. During her time at college, she had the opportunity to participate in and to be an historical witness to the modernization of the interior of São Paulo.

The second half of the twentieth century represented a new phase of human development, with the world economy and the social progress aligning in the reconstruction of the national social fabric, which expected to be able to include those who were out of its orbit through joining technology and a welfare state. In social terms, the ruling groups of earlier times were replaced by intense mobility, found in the expansion of the middle class and the large working class. In Brazil, to the process of economic growth joined the belief in the viability of a modern, civilized country ${ }^{2}$.

When the lenses of this spirit of the times turn to the regional realities, however, some themes guide these contexts and, in the case of São Paulo, this post war modernization, allied with a movement of educational change to remedy the low educational level of provincial population, an issue which has always been a motive for discussion among the elite of São Paulo, understood as a fundamental process and a state integrator.

Then, with the renewal of the small town teachers, especially geared to secondary education, came the chance for some to pursue an academic career, especially at the University of São Paulo (USP). With the intensification of industrial internalization, this impulse in the educational field was relatively quick in some cities, even with local conflicts about the fact that it would be dangerous to educate a "new" intellectual elite ${ }^{3}$. In this context, in 1957, six new faculties of philosophy, science and literature were created in the interior of São Paulo. Araraquara even received international forums, including the visit and participation of the French writer and philosopher Jean Paul Sartre on September 4, 1960, which had repercussions in the Philosophy College, which became the meeting point for the most well-informed diverse groups in the city ${ }^{4}$.

In the midst of this regional imperatives, the Pedagogy course brought a rich discussion about the fate of Brazilian education as a support to national development and modernization, combining the educational research and teaching policy with the developmentalist ideology which prevailed in the country in that context, and considered the educational system as a resource to overcome Brazilian barriers 5 . It is at this point, that Social Sciences took on an important role ${ }^{2}$.

Araraquara entered this process when Luiz Pereira took the chair of Sociology as a teacher in the course of Pedagogy. Egressed from USP, to which he would return later, he was seen as a selftaught sociologist, with important and original theoretical contributions to scientific knowledge, updating the dialogue of his master, Florestan Fernandes, with the main currents of Social Science thought ${ }^{6}$.

Among key theoretical issues, problems with respect to popular education and the responsibilities of the social sciences were also found. Pereira's work brought about a new era in Brazilian Sociology history, a new way of thinking about 
the configuration and the movements of society ${ }^{6}$, which intended to conduct an extensive empirical panorama of Brazilian reality through 'community studies', aimed at the 'sociology of development', making clear the belief in the possibility of direct 'application' of sociological knowledge in public policy?.

And it was during this process of change within their own sociological field and from the perspective of the importance of education to promote social development that there was a meeting between Luiz Pereira and Cecilia Donnangelo. There is no doubt that the sociological and educational guidelines which he delivered were relevant to the formation of the first Pedagogy classes, and especially to the development of Cecilia, in particular.

\section{The production of Cecilia Donnangelo and the social issue in Health}

To follow as closely as possible the research production of knowledge of her teacher and, later, mentor, Luiz Pereira, Cecilia centered her thinking upon a new type of education which articulated social questions in search of answers to some medical sanitary barriers, decisive for her first experiences, both academic and educational, at the Faculty of Medicine at USP ${ }^{1}$.

Consistent with such influences, the work of Donnangelo mirrored the triangulation of education, sociology and medicine, exploring it through the Marxist historical framework and always involved with the perspective of public policy: her doctorate and first book dealt with the study of the medical labor market in dialogue with the State's role in health care and health policy. One of her last works, printed only in mimeographed form, dealt with health education and health policy in the country ${ }^{8}$.

Thus, her work critically combined the theme brought into the dialogue established by national developmentalism with medical and sanitary issues. In it, productivity and Brazilian Health would break the cycle of poverty, malnutrition, poor housing and illness through the adoption of preventive measures, which would also overcome the gap between the coast and hinterland, still considered abandoned in the sanitary-medical field?.

Internationally, there was a scenario brought about by social and intellectual movements focused on the so-called Community Medicine, which, based on the establishment of community health centers subsidized by the State, and administered by non-profit organizations, would provide basic health care. The proposal of Community Medicine, in the case of the United States, managed to implement some of the preventive practices focusing on minority social sectors, but left untouched the social hegemony of the conventional medical care, as Donnangelo well-presented in her second book ${ }^{8,10}$.

It turns out that such a design necessarily involves the training of physicians and the need to reformulate the current educational standard: a larger horizontal and vertical coordination of existing disciplines, as a form of "integration" of partial fields of medical knowledge; and the introduction of new disciplines considered basic, which would include psychology, social sciences, ecology, anthropology, here seen mainly as behavioral sciences. These would be forms of educational practices able to shape a global vision of the individual and such fields of knowledge would fit together, perfectly, in departments of Preventive Medicine ${ }^{11}$.

These questions are relevant to a broader understanding of the motivations which brought Cecilia closer to the medical and sanitary fields. Furthermore, it was from her school experience in a region known as "the mouth of the São Paulo hinderland" - Araraquara and neighbor cities—and her activities in secondary teaching, that arose her first hypotheses linking learning and social and sanitary questions. As a teacher of sociology and psychology at a State Teaching School (In the original, "Escola Normal do Estado": a high school model aimed at preparing primary school teachers) and as a coordinator of the course programs, she designed and supervised a research project involving various school areas, performed by students, with students of primary schools, relating to problems of nutrition, poverty and academic productivity.

Thanks to this research came contacts with medical professionals and an invitation to lecture in the discipline of Social and Legal Medicine at the Faculty of Medicine at USP, which then showed interest in implementing a program of social sciences in the graduation course. Gradually, however, it became clear that the sociological orientation which she tried to implement in terms of behavioral rating, in the style of Nina Rodrigues, led to the gradual withdraw of Cecilia Donnangelo and her approximation to another medical field of knowledge, then called Preventive Medicine.

So, if she had entered as a teacher in 1964 in the discipline of Social and Legal Medicine ${ }^{8}$, in 
1969 she had started working in the newly created Department of Preventive Medicine as "educational instructor", at the invitation of the then Head of the Department Guilherme Rodrigues da Silva:

[...] Professor Guilherme Rodrigues da Silva, coordinator of the Department of Preventive Medicine from the time of the hiring of Cecilia, wrote in his testimony: But, even with all our working together, something that was never clear to me was why she chose to work with Medicine, specifically. Without doubt, regardless of wanting to explain an individual option, we can say that the theme of Medicine and Health emerged with great force in the mid-1960's at the international level and WHO/PAHO promoted numerous discussions to introduce an educational model that went beyond the biomedical centrality. Thus, the Social Sciences appeared in the medical setting, and the first sociologists are hired ${ }^{12}$.

Her formation in the educational field led Donnangelo to excel at the didactic organization of disciplines she taught in the Department. In this sense, she gave priority to formation rather than academicism, and despite criticism suffered, this was an absolutely conscious option ${ }^{13}$. Such criticism may have been due to the intense struggle for the reform of medical education then occurring at the medical school, in which she played a strong role, actively participating in a new curricular proposal, the Experimental Course of Medicine. This proposal integrated the disciplines from the standpoint of an innovative methodology, aiming at implementing a medical course which would prepare more capacitated professionals, clearly incorporating and deepening the social aspects of medicine and health.

In terms of scientific production, Donnangelo adopted a critical sociological perspective in the field of health, moving away from the usual sociological medical perspective, in which the medical profession and practice are seen through the lenses of the physician's questions. In fact, in her studies the reverse is true, it deals with the profession as a market and as a practice carried out in an articulate manner with the social and political structure as historically given. Each of these themes was addressed in two fundamental works which approaches the field of Collective Health, arising from her doctoral thesis and associate professor thesis. The first, Medicine and Society $^{14}$, inaugurated in the country the knowledge about the production and distribution of medical services in society. Furthermore, it discusses medical work in this market as well as the role and actions of the State in these matters, showing that the medical profession is also a matter of public policy. It was, therefore, innovative recognition of the social aspect in professional corporative issues, with respect to the regulatory role of the modern State and the political economics of health services.

In her second work ${ }^{10}$, another innovative contribution, highlighting the social aspect within the technical dimension of medical practice itself, showing the consubstantiality of these two dimensions, technical and social. She showed this consubstantiality in two points of the process we call medicalization: increasingly medicine expands its normative domains in society, as a medicalization of social aspects in the world; at the same time as it calls for instrumental manipulative features of the social aspect in medicine, reducing the complexity of the world to medically operable behaviors through medical intervention.

If, at first glance, we find that both studies show the same concern with the relationship between the social and medicine, as the axis of the social issues in health, further examination allows us to point out a certain displacement of her analytical look, which is reinforced by the review of a third unprecedented work, dealing with sanitary education in terms of health policy. Or, as Schraiber ${ }^{15}$ stated: The displacement can be seen as the transition from one conception of health politicization to another, being this intention of politicizing the alleged neutrality of techniques, a central constitutive element of the movement, of the proposal and the project of Collective Health.

We consider, first, that the very inscription of the need to politicize health is due to the invisibility of the social in this field, marked by the split between its technical and scientific dimension, on the one hand and its practical impact on society on the other. This split opposes and isolates each one, resulting in an understanding of health as only a techno-scientific domain. This view is based on how physicians perceive medicine, politically and ideologically, building for themselves a concept of disease and intervention based on "the individual clinical case" and considering anything collective, as well as the social itself, as the sum of these cases ${ }^{15}$.

Donnangelo argued that a major difficulty physicians have to see how changes in their practice link with social changes, comes from the antiquity of this practice, which somehow makes it easier to take it as a permanent intervention throughout history. In her words: [...] unlike oth- 
er social practices, whose origin is coincident with the very emergence or the development of capitalist society, medicine tends to more easily put on a neutral character in the face of the specific determinations it acquires in a society of classes. [...] Yet, this conception [...] finds in the historical continuity of medicine one of its main support. Medical practice and its agents have not been established within the capitalist mode of production ${ }^{10}$.

Thus, a first politicizing movement in the work of Donnangelo was to show this presence of the social, point out its economic and political connections and their historical determinations on professional practice, the organization of the labor market for physicians and ways of producing medical care for the population. All this within the connection between medicine and the policies of the modern State. This is, in our view, an assertion of the social in health and medical issues, in face of its denial in professional discourses and in their occupational ideologies, developing the referred concept of medicalization of that society, in this first moment and in her first book, the way we produce and consume medical care and its byproducts.

The second time she addressed the social, which may be seen in her second book, seems to advance the development of this concept. Medicalization becomes a way of reading and interpreting the social within the conceptual framework of Medicine. Seen in this light, the social factor is not absent, but transmuted into individual behaviors related to sickness. In these terms, medicalization becomes a historical construction of sociocultural reference, which, like other conceptional constructions, functions as a reference for the thinking and actions of society. It is capable of organizing life, materially and symbolically. But this outlook brings a way of seeing the social inscribed in medicine, which retracts its sociality, its political quality as a whole, relative to the individual illness and restorative or preventive intervention. It is the social reduced to the individual case and not this individual as an expression of the plurality of the social; a way of taking the presence and influences of the social which is not social at all ${ }^{15}$. This medicalization is also a form of health education which, as a tool of public policy, a form of acculturation of all in the perspective that health becomes only the consumption of medicine and its byproducts.

The contribution of Donnangelos' work, therefore, not only remains in the triangulation of education, sociology and medicine, but also represents new theoretical and epistemological pathways, with repercussions in the knowledge of the social, the cultural and the political areas as related to health questions.

\section{Cecilia from different viewpoints and biographical notes}

We conclude this text bringing other points of view, in addition to our considerations. This way of concluding her presentation seemed important to us as it effectively shows us her broad presence in the field.

In the very recent publication ${ }^{16}$, in 2014, Jose da Rocha Cavalheiro, Luiza Sterman Heimann and Marcio Derbli, researchers at the Health Institute of São Paulo State Health Secretariat (Instituto de Saúde da Secretaria da Saúde de São Paulo) organizes the selection "The social epidemiology - a legacy of Cecilia Donnangelo". In addition to several commentators on Cecilia's work, the selection contains a transcript of her unpublished lecture delivered at an epidemiology course offered by the Association of the Sociologists of São Paulo State (Associação dos Sociólogos do Estado de São Paulo), in October, 1982.

In this text the similarities and differences between the social perspectives adopted by two different currents of epidemiological thought were addressed: classical epidemiology and social epidemiology. According to the organizers of this beautiful work of historical recuperation: This work reveals a little-known contribution of Cecilia Donnangelo in an area which rarely was a specific object of study, in a remarkable production from the early days of the Brazilian effort to build the field of Collective Health ${ }^{16}$.

Gastão Wagner de Souza Campos, student, admirer and multiplier of the questions raised by Cecilia in quite innovative and important contributions for politics, planning and health management, in 2011 writes the preface of the second edition of the first book of Donnangelo. In an emotional and moving text, he clearly states her scientific and political contributions and deservingly presenting her as the great educator she was, a master. Textually: Cecilia Donnangelo is someone we miss... We miss studying the health policy of the third millennium in Brazil, with our Master's freedom of movement, methodological and interpretative rigor, and the opening to the concrete beyond theoretical boundaries ${ }^{17}$.

Everardo Duarte Nunes, contemporary of Cecilia Donnangelo, a noted intellectual and also a participant in the creation of the Social Sciences in Collective Health, has dedicated himself to, 
among other things, keeping alive both the memory of the origins and the historical development in the Collective Health area and the sub-area of the Social Sciences in Health. About her, whom he treats as a pioneer in the theoretical construction of social thinking in health, he wrote: Indeed, the influences of Cecilia were distributed and seized by her followers within a perspective that assured them advances and innovations in the spirit which guided her intellectual presence- to contribute to critical reflection and theoretical elaboration ${ }^{12}$.

Finally, and in reality the first, we have Ricardo Bruno Mendes Gonçalves, he himself a great intellectual, researcher and professor of Preventive Medicine, who worked with Cecilia at USP. He was her closest collaborator and interlocutionist. He wrote two short texts about her at the year of her death, in 1983, published in Abrasco Bulletin 5, although he didn't sign the text; and in 1982, opening "Health and Society" journal, in its first issue, first volume. In his words: Cecilia Donnangelo managed to surpass herself as a social scientist and achieved a much more important meaning. For having been able to unite, with the creative fertility which characterized and distinguished her, the academic research activity with a dedication to teaching, with the lucid guidance to all who sought her aid, with the spreading and passionate defense of her dedication to history, made her death even more tragic, made her life a task which cannot be discontinued ${ }^{18}$.

By the strength of her presence, now mediated by the practice of a crowd of health workers she directly and indirectly helped to form, Cecilia Donnangelo is one of the pillars upon which Collective Health was built as an area of work vividly attentive to the relationship between the pulsation of social commitment and the requirements of professional seriousness. While this is so, she will stay alive $^{19}$.

All of this information takes into account how memory will always be an alive ground, moved by the circumstances of the writer. A biographical subject, then, would ideally have a mark of the times as an open work of historical dimension. However, convergent aspects of these narratives delineate certain matrices able to confirm that which someone brought as her first objective. This was the case of Cecilia Donnangelo as she addressed the relevance of the social in health for yesterday, and, as treated by her commentators, for the days that follow as well.

\section{Collaborations}

LB Schraiber and A Mota participated equally in all stages of preparation of the article.

\section{Acknowledgements}

The authors are grateful to FAPESP (Projeto História da Saúde Coletiva no estado de São Paulo: emergência e desenvolvimento de campo de saber e práticas) for the financial support and to CNPq (Bolsa produtividade 1-A). 


\section{References}

1. Mota A, Schraiber LB. A pedagoga Maria Cecilia Ferro Donnangelo, 1940-1983: restos de memória, indícios para a história. In: Carvalheiro JR, Heimann LS, Derblio M, organizadores. O social na epidemiologia: um legado de Cecilia Donnangelo. São Paulo: Instituto de Saúde; 2014. p. 27-46.

2. Arruda MAN. Metrópole e cultura: o novo modernismo paulista em meados do século. Tempo Social - Revista de Sociologia da USP 1997; 9:39-52.

3. Vaidergorn J. As seis irmãs - as Faculdades de Filosofia, Ciências e Letras: institutos isolados de ensino superior no estado de São Paulo - 1957-1964 [tese]. Campinas: Universidade Estadual de Campinas; 1995.

4. Medina-Junior C. Bem-vindos a nossa história: Teatro Experimental de Comédia de Araraquara (1955-1962) [tese]. Campinas: Universidade Estadual de Campinas; 2009.

5. Mendonça AWPC. Pragmatismo e desenvolvimentismo no pensamento educacional brasileiro dos anos de 1950/1960. Rev Brasileira de Educação 2006; 11(31):96113.

6. Ianni O. A sociologia de Florestan Fernandes. Estudos Avançados 1996; 10(26):25-33.

7. Jackson LC. Gerações pioneiras na sociologia paulista (1934-1969). Tempo Social - Revista de Sociologia da USP 2007; 19(1):115-130.

8. Mota A, Silva JA, Schraiber LB. Contribuições pragmáticas para a organização dos recursos humanos em saúde a para a história da profissão médica no Brasil à obra de Maria Cecilia Donnangelo. Brasília: Ministério da Saúde; 2004.

9. Hochman G. O Brasil não é só doença: o programa de saúde pública de Juscelino Kubitschek. História, Ciência, Saúde - Manguinhos 2009; 16(Supl. 1):313-331.

10. Donnangelo MCF, Pereira L. Saúde e sociedade. São Paulo: Hucitec; 2011.
11. Silva GR. Origens da Medicina Preventiva como disciplina do ensino médico. Rev. Hosp. Clín. Fac. Med. São Paulo 1973; 28:91-96.

12. Nunes ED. Cecilia Donnangelo: pioneira na construção teórica de um pensamento social em saúde. Cien Saude Colet 2008; 13(3):909-916.

13. Chassot WCF. Memórias de origens: Hospital Universitário da Universidade de São Paulo, 20 anos. São Paulo: Hospital Universitário-USP; 2001.

14. Donnangelo MCF. Medicina e sociedade. São Paulo: Pioneira; 1975.

15. Schraiber LB. O Social e a Saúde no pensamento de Cecília Donnangelo, São Paulo: Instituto de Saúde, 2014. Texto de fala proferida no IX Congresso brasileiro de Epidemiologia em 10/09/2014. [acessado 2015 jan 24]. Disponível em: http://www.saude.sp.gov.br/resources/ instituto-de-saude/homepage/temas-saude-coletiva/ pdfs/sessao_lilia_blima.pdf

16. Carvalheiro JR, Heimann LS, Derblio M, organizadores. O social na epidemiologia: um legado de Cecilia Donnangelo. São Paulo: Instituto de Saúde; 2014.

17. Campos GWS. Prefácio. In: Donnangelo MCF. Medicina e sociedade. $2^{\text {a }}$ ed. São Paulo: Hucitec; 2011. p. 9-12.

18. Abrasco. Cecilia Donnangelo (1940-1983). Boletim da Associação Brasileira de Pos-Graduação em Saúde Coletiva 1983; 5:2.

19. Mendes-Gonçalves RB. Cecilia Donnangelo hoje. Saúde Soc. 1992; 1(1):3-5.

Article submitted 03/09/2014

Approved 24/02/2015 
